\title{
Vascular Effects of Arginine Vasopressin during Fluid Deprivation in the Rat
}

\author{
Gary A. Aisenbrey, William A. Handelman, Patricia Arnold, \\ Maurice Manning, and Robert W. Schrier, Department of Medicine, \\ University of Colorado Health Sciences Center, Denver, Colorado 80262; \\ Department of Biochemistry, Medical College of Ohio, Toledo, Ohio 43614
}

A B S T R A C T The vascular effects of arginine vasopressin (AVP) were examined in conscious SpragueDawley rats. In six control rats, synthetic AVP at a dose of $40 \mathrm{ng} / \mathrm{kg}$, injected as an intravenous bolus, resulted in a rise in mean arterial blood pressure (BP) from 127 to $149 \mathrm{~mm} \mathrm{Hg}(P<0.005)$. No tachyphylaxis was observed after a second AVP bolus administered $30 \mathrm{~min}$ later, as BP increased from 125 to $150 \mathrm{~mm} \mathrm{Hg}, P<0.005$. In a second group of six rats, 1-deamino penicillamine, 2-(O-methyl) tyrosine AVP ([dPTyr (Me)]AVP), was administered intravenously at a dose of $10 \mu \mathrm{g} / \mathrm{kg}$, just before the second AVP bolus. In this group of studies $\mathrm{BP}$ rose from 124 to $150 \mathrm{~mm} \mathrm{Hg}(P<0.01)$ after the first AVP bolus, but not after the second AVP bolus, which was administered after [dPTyr (Me)]AVP (129 vs. 129 $\mathrm{mm} \mathrm{Hg}, \mathrm{NS}$ ). To assess the effect of this AVP pressor antagonist on BP in rats with suppressed endogenous vasopressin, six water-diuresing rats (mean urinary osmolality, $99 \mathrm{mosmol} / \mathrm{kg} \mathrm{H}_{2} \mathrm{O}$ ) were administered the analogue at the same dose as the first group of rats. The analogue exerted no demonstrable effect on mean BP (128 before vs. $129 \mathrm{~mm} \mathrm{Hg}$ after [dPTyr (Me)]AVP, NS). In these rats, mean radioimmunoassayable levels of AVP were at or below the detectable limits of our assay $(0.5 \mathrm{pg} / \mathrm{ml})$. In contrast, six rats in which endogenous AVP was stimulated by fluid deprivation for $24 \mathrm{~h}$ (mean urinary osmolality, $2,489 \mathrm{mosmol} / \mathrm{kg} \mathrm{H}_{2} \mathrm{O}$ and mean AVP level of $21.6 \mathrm{pg} / \mathrm{ml}$ ) had a marked fall in $\mathrm{BP}$ when administered the AVP analogue. In these animals [dPTyr (Me)]AVP caused a fall in BP from 124 to $110 \mathrm{~mm} \mathrm{Hg}(P<0.005)$. This fall in blood pressure was due to a fall in peripheral vascular resistance $(0.35$ vs. $0.30 \mathrm{~mm} \mathrm{Hg} / \mathrm{ml}$ per min per $\mathrm{kg}, P<0.02)$ after [dPTyr (Me)]AVP, as cardiac index remained unchanged.

Mr. Aisenbrey is the recipient of the Outstanding Medical Research Award for 1980-81 at the University of Colorado School of Medicine for research reported in this paper.

Received for publication 1 November 1979 and in revised form 5 December 1980.
To eliminate the possibility that this AVP analogue was antagonistic to endogenous pressor substances other than AVP, additional studies were performed. In homozygous Brattleboro (diabetes insipidus) rats receiving exogenous AVP, the vasopressin analogue lowered BP ( 133 to $112 \mathrm{~mm} \mathrm{Hg}, P<0.001$ ), but failed to lower BP (112 vs. $112 \mathrm{~mm} \mathrm{Hg}$ ) in rats not receiving AVP. BP in a group of bilaterally nephrectomized Sprague-Dawley rats, after $24 \mathrm{~h}$ of fluid deprivation, fell from 130 to $118 \mathrm{~mm} \mathrm{Hg}(P<0.02)$ after the AVP analogue, precluding an effect of the analogue on lowering BP by inhibiting the renin-angiotensin system. Finally, the AVP analogue failed to alter the pressor response to exogenous infusions of either norepinephrine or angiotensin II. These results demonstrate that $(a)$ the AVP analogue [dPTyr (Me)]AVP abolishes the pressor effect of large exogenous doses of AVP; $(b)$ the analogue has no effect on BP in rats with suppressed or absent endogenous AVP; $(c)$ the depressor effect of the analogue does not involve antagonism of the vasoconstrictors, norepinephrine or angiotensin; and $(d)$ most importantly, BP fell significantly after AVP antagonist administration in intact, conscious, fluid-deprived rats with elevated endogenous AVP levels. This effect of the AVP antagonist to block endogenous AVP and lower BP was primarily due to a fall in peripheral vascular resistance.

\section{INTRODUCTION}

The pressor activity of arginine vasopressin $(\mathrm{AVP})^{1}$ has been known since 1898 (1). However, it has been difficult to document whether this vasopressor activity of AVP is of physiological or pathophysiological importance. On the other hand, there can be little doubt about the importance of the antidiuretic activity of AVP

\footnotetext{
${ }^{1}$ Abbreviations used in this paper: AVP, arginine vasopressin; AII, angiotensin II; [dPTyr (Me)]AVP, l-deamino penicillamine, $2-(O$-methyl $)$ tyrosine.
} 
in osmoregulation of body fluids. In addition to the osmoregulation of AVP release, however, it is now clear that a nonosmotic pathway for AVP release exists which is dependent on the integrity of low and high pressure baroreceptor activity $(2,3)$. Indeed, it has been hypothesized that the nonosmotic release of AVP may have originally constituted an integral part of the alarm reaction, so that the vasoconstrictor properties of AVP were of tantamount importance during periods of stress (4). This may have been particularly true in seaforming species, in which rapid responses to stress may have been more critical than water conservation. In support of this hypothesis are the numerous circumstances in which the nonosmotic release of AVP may occur in the setting of increased adrenergic neural tone, including volume depletion, hypotension, adrenal insufficiency, acute cardiac failure, and emotional and physical stress. Because a decrease in parasympathetic afferent tone has been shown to stimulate the nonosmotic release of AVP (5), baroreceptor-mediated release of AVP in the setting of increased sympathetic activity and stress might indeed be expected. However, whether the nonosmotic release of AVP is of importance only in renal water conservation or whether it exerts a vasoconstrictor effect on blood vessels is not known. It is known that the exogenous doses of AVP necessary to cause a pressor response are substantially larger than the doses necessary to cause an antidiuresis. However, although a 5-10\% decrease in blood volume appears necessary to cause the release of AVP, once this nonosmotic pathway is stimulated, a geometric rise in AVP occurs (6). Thus, it is reasonable to suggest that in some physiological and pathophysiological circumstances, plasma AVP may reach a level which is associated with vasoconstriction of blood vessels.

Until recently, the experimental tools necessary to test this hypothesis were not available. Manning et al. (8), however, have recently developed some analogues of AVP that are antagonistic to the vasopressor properties of AVP. In the present study, one such analogue, 1-deamino penicillamine, 2-( $O$-methyl $)$ tyrosine AVP ([dPTyr (Me)]AVP), was used to study the role of endogenous AVP in circulatory homeostasis in the conscious rat. The results indicate that endogenous AVP exerts profound vasoconstrictor effects in the conscious rat after $24 \mathrm{~h}$ of fluid deprivation. This vasoconstriction serves to maintain blood pressure by increasing total peripheral vascular resistance as renal and hepatic arterial blood flow is diminished.

\section{METHODS}

Male Sprague-Dawley rats weighing 150-250 g were anesthetized with ether. Polyethylene cannulas were inserted into a jugular vein and femoral artery for the injections and measurement of arterial blood pressure, respectively. Mean arterial blood pressures were calculated electronically and recorded on a Hewlett-Packard recorder (model 7702B HewlettPackard Co., Palo Alto, Calif.). All rats were given $1 \mathrm{ml}$ of $0.9 \%$ saline to compensate for estimated fluid losses. Following the surgical procedures, the rats were placed in individual restraining units (Narco Bio-Systems, Inc., Houston, Tex.) and were studied after a 60 -min recovery period in a conscious state according to one of seven protocols.

Exogenous AVP with and without AVP antagonist. In these experiments, 12 rats were studied. After a steady-state control period, an intravenous bolus of synthetic AVP was given in a dose of $40 \mathrm{ng} / \mathrm{kg}$ to six rats. This dose had previously been determined to cause a mean increase in blood pressure of $25 \mathrm{~mm} \mathrm{Hg}$. $30 \mathrm{~min}$ later, after recovery from the first AVP bolus, the AVP antagonist [dPTyr (Me)]AVP ${ }^{2}$ was given in a dose of $10 \mu \mathrm{g} / \mathrm{kg}$. $10 \mathrm{~min}$ later, a second bolus of AVP was administered in the same dose of $40 \mathrm{ng} / \mathrm{kg}$. Six control rats were also prepared according to an identical experimental design except that a blank solution of $0.9 \%$ saline was administered in place of the [dPTyr (Me)]AVP. To test the dose response of the AVP antagonist, a group of five rats was studied with four sequential $40 \mathrm{ng} / \mathrm{kg}$ doses of AVP. No AVP antagonist was given before the first bolus of AVP, then doses of $0.5,5$, and $10 \mu \mathrm{g} / \mathrm{kg}$ of the AVP antagonist preceded the next three boluses of AVP, respectively.

AVP antagonist in water-diuresing rats, rats after $24 \mathrm{~h}$ of fuid deprivation, and Brattleboro rats. The responses of six rats were examined according to the following protocol. During a 60-min equilibration period, a sustaining solution of hypotonic saline $(0.4 \%)$ was infused at a rate of $0.2 \mathrm{ml} / \mathrm{min}$. When a stable water diuresis was achieved, as determined by urine flow and urine osmolality, mean arterial pressure was recorded, then intravenous [dPTyr (Me)]AVP was administered at a dose of $10 \mu \mathrm{g} / \mathrm{kg}$.

Another six rats were deprived of water for $24 \mathrm{~h}$ before the experiment. After collection of a spontaneous urine sample from rats in a balance cage for measurement of urinary osmolality, the rats were studied according to the above protocol. Urine volume was measured volumetrically.

A group of five Brattleboro rats homozygous for diabetes insipidus was allowed to drink and eat ad lib. prior to study. In these rats base-line plasma osmolality in $332 \mathrm{mosmol} / \mathrm{kg}$ $\mathrm{H}_{2} \mathrm{O}$ (12) compared with $302 \mathrm{mosmol} / \mathrm{kg} \mathrm{H}_{2} \mathrm{O}$ in SpragueDawley rats after $24 \mathrm{~h}$ of fluid deprivation. After a steadystate control period, intravenous [dPTyr (Me)]AVP was administered at a dose of $10 \mu \mathrm{g} / \mathrm{kg}$, and blood pressure response recorded.

AVP antagonist in Brattleboro rats receiving exogenous $A V P$. In addition to the above experiments, further support for the specificity of the AVP antagonist was obtained in another group of five Brattleboro rats on ad lib. food and water. After a steady-state control period, a constant infusion of synthetic AVP was begun $(5 \mathrm{ng} / \mathrm{kg}$ per $\mathrm{min})$, a dose determined to cause approximately a $15 \mathrm{~mm} \mathrm{Hg}$ rise in blood pressure. After blood pressure had stabilized, the infusion was discontinued and postcontrol blood pressures were recorded. Following a 45-min equilibration period, the AVP infusion was restarted. After the pressor effects of the infusion had stabilized again, [dPTyr (Me)]AVP $(10 \mu \mathrm{g} / \mathrm{kg})$ was injected and the effect on blood pressure was recorded. Plasma AVP levels

\footnotetext{
${ }^{2}$ In the synthesis of the analogue, the terminal cysteine residue of AVP is replaced by a deamino penicillamine residue. This precludes the possibility of contamination with AVP, since cysteine is not added during the synthesis procedures and therefore cannot be present in the molecule. Thus, AVP cannot be present, since it requires the presence of cysteine in its molecule.
} 
during the AVP infusion were determined in an additional group of six rats. After a steady-state control period, AVP ( $5 \mathrm{ng} / \mathrm{kg}$ per $\mathrm{min}$ ) was administered. Again, after stabilization of the AVP pressor action, $2 \mathrm{ml}$ of blood was rapidly removed from the femoral arterial catheter and placed in chilled EDTA tubes. Following centrifugation, plasma aspirates were assayed for AVP according to previously described methods (10).

AVP antagonist in nephrectomized rats after $24 h$ of fluid deprivation. Six rats were anesthetized with intraperitoneal pentobarbital $(10 \mathrm{mg} / \mathrm{kg})$ and bilaterally nephrectomized through a midabdominal incision. $24 \mathrm{~h}$ later, during which time no fluid intake was allowed, the rat's response to [dPTyr (Me)]AVP was examined using the same protocol cited above. After each experiment, blood was collected into chilled $\mathrm{K}_{3}$ EDTA tubes. The tubes were centrifugated and the plasma fraction was used for measurement of plasma renin activity.

AVP antagonist in rats receiving exogenous angiotensin II. Although the above experiments in nephrectomized rats were performed to demonstrate that the AVP antagonist does not require the presence of angiotensin for its depressor activity, the following additional studies were performed to exclude the possibility that this analogue may have anti-angiotensin activity. In six rats, after a steady-state control period, a constant infusion of angiotensin II (AII) $(0.3 \mu \mathrm{g} / \mathrm{kg}$ per min) was given. After stabilization of the pressor action of AII, the infusion was stopped and postcontrol recordings were obtained. Following a 45-min equilibration period, the AII infusion was begun again. After blood pressure had again stabilized, [dPTyr (Me)]AVP (10 $\mu \mathrm{g} / \mathrm{kg}$ ) was injected and the effect on blood pressure was recorded.

AVP antagonist in rats receiving exogenous norepinephrine. To test further the specificity of the AVP antagonist, the effect of [dPTyr (Me)]AVP on the pressor response to norepinephrine was tested. In five rats, after a steady-state control period, a constant infusion of norepinephrine was begun at 4 $\mu \mathrm{g} / \mathrm{kg}$ per min. After a constant pressor dose of norepinephrine was achieved, the infusion was discontinued and postcontrol pressures were recorded. The infusion was then restarted, and again after blood pressure had stabilized, $10 \mu \mathrm{g} / \mathrm{kg}$ of [dPTyr (Me)]AVP was injected to examine the effect on blood pressure. A postcontrol period was obtained after discontinuation of the norepinephrine infusion.

Hemodynamic studies in 24-h fluid-deprived rats. $1124-\mathrm{h}$ fluid-deprived rats were studied in this protocol. Five of the rats received a $0.9 \%$ saline blank solution, and the other six rats received [dPTyr (Me)]AVP in a dose of $10 \mu \mathrm{g} / \mathrm{kg} 10 \mathrm{~min}$ prior to the injection of the microspheres. Each rat was cannulated with tapered PE 350 tubing through the femoral artery for blood collection, and into the left ventricle via the right carotid artery for microsphere injection. Ventricular cannulation was confirmed by pressure wave tracing at the time of catheterization and direct observation at the conclusion of each experiment. A 60-min equilibration period was then allowed before determination of cardiac output and renal blood flow by a radioactive microsphere technique (7). The microspheres used were $15 \mu \mathrm{m}$ in diameter and were labeled with ${ }^{85} \mathrm{Sr}$. For each determination, $0.2 \mathrm{ml}$ of a $10 \%$ dextran solution containing 500,000 microspheres $/ \mathrm{ml}$ was injected through the carotid catheter in 5-7 s. The catheter was flushed with $0.2 \mathrm{ml}$ of $0.9 \%$ saline. Before filling the syringes, the solution containing the microspheres was placed in a Bio-Vial, and the radioactivity counted for $1 \mathrm{~min}$ with a Beckman Biogamma counter (Beckman Instruments, Fullerton, Calif.). The solution was then vigorously agitated with a Vortex mixer for a minimum of $5 \mathrm{~min}$. The syringe for injection was filled and injected into the rat within $60 \mathrm{~s}$ of mixing. The femoral catheter was opened $10 \mathrm{~s}$ before microsphere injection, and blood was collected at a constant withdrawal rate of $0.6 \mathrm{ml} / \mathrm{min}$ for $2 \mathrm{~min}$.
After femoral blood collection, $0.2 \mathrm{ml}$ of blood was withdrawn from the carotid catheter to clear it of microspheres and placed in the original Bio-Vial used to determine preinjection radioactivity. Evaluation of carotid catheters for residual counts showed no radioactivity above background. The injection syringe was then flushed several times with normal saline into the original Bio-Vial, and the Bio-Vial was then counted to determine postinjection counts. This value was then subtracted from the preinjection counts to yield total counts injected. Mean arterial pressure was measured prior to each microsphere injection, using a Hewlett-Packard recorder and transducer connected to the femoral catheter. Following collection of femoral blood, each animal was sacrificed, and the kidneys were removed, decapsulated, and weighed. The liver and brain were also removed, and all tissues were placed in $10 \%$ formalin for $24 \mathrm{~h}$. The kidneys, liver, brain, and blood samples were then counted for ${ }^{85} \mathrm{Sr}$.

Renal blood flow (RBF) was calculated as kidney (counts per minute per gram kidney wt)/femoral blood (counts per minute) $\times$ femoral flow rate (milliliters per minute). Total renal vascular resistance was calculated as mean arterial pressure/mean RBF per two kidneys. Cardiac index (CI) was calculated as counts per minute injected/femoral blood (counts per minute) $\times$ femoral blood flow rate (milliliters per minute per kilogram body wt). Total peripheral vascular resistance was calculated as mean arterial pressure/CI. Total cerebral blood flow was calculated as brain (counts per minute per gram brain wt)/femoral blood (counts per minute) $\times$ femoral flow rate (milliliters per minute). Total hepatic arterial blood flow was calculated as liver (counts per minute per gram liver wt)/ femoral blood (counts per minute) $\times$ femoral flow rate (milliliters per minute).

Measurement of plasma AVP and plasma renin activity. Plasma AVP was measured by a radioimmunoassay technique using a modification of the method of Robertson et al. (9) and previously reported from this laboratory (10). Separate groups of either six water-diuresing or six 24-h fluid-deprived rats were decapitated by guillotine and the blood was collected into chilled $\mathrm{K}_{3}$ EDTA tubes. Vasopressin concentrations were expressed as picograms per milliliter.

Plasma renin activity was measured by radioimmunoassay of angiotensin with use of the method of Stockigt et al. (11). The results were expressed as nanograms of angiotensin I generated per milliliter per hour.

Statistical methods. When paired sets of data were compared, the Student's paired $t$ test was used. When multiple comparisons were made, Scheffe's test of multiple comparisons was used. When unpaired sets of data were compared, the Student's unpaired $t$ test was used. Statistical significance was expressed as the $P$ value.

\section{RESULTS}

Effect of AVP antagonist on pressor response to AVP. The effect of the AVP antagonist on the pressor response to two sequential intravenous boluses of AVP is shown in Fig. 1A. The first bolus of AVP significantly increased mean arterial pressure from $125 \pm 3.1$ to $150 \pm 6.6 \mathrm{~mm} \mathrm{Hg}(P<0.01)$. However, when the same dose of AVP was administered after the AVP antagonist, mean arterial pressure remained unchanged at $129 \pm 4.55$ vs. $128 \pm 5.3 \mathrm{~mm} \mathrm{Hg}$. The lack of effect of the blank solution on the pressor response to sequential boluses of AVP is shown in Fig. 1B. Mean arterial pressure increased from $127 \pm 3.2$ to $149 \pm 3.7 \mathrm{~mm} \mathrm{Hg}(P<0.005)$ 

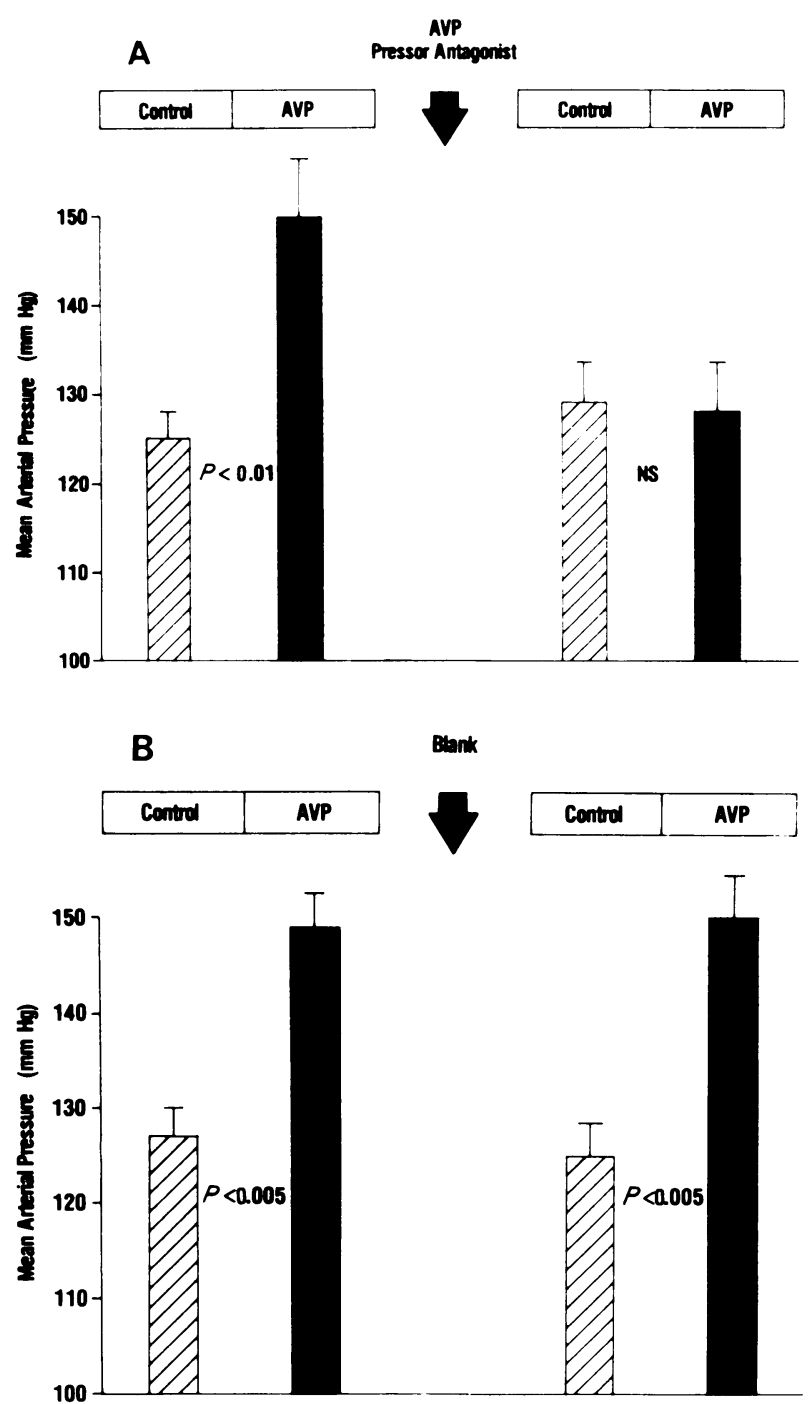

FIgURE 1 Comparison of AVP pressor antagonist (A) and blank (B) on sequential pressor response to AVP.

with the first bolus of AVP, and after the blank solution the second bolus of AVP increased blood pressure to the same degree, from $125 \pm 3.5$ to $150 \pm 4.5 \mathrm{~mm} \mathrm{Hg}$ $(P<0.005)$. In the group of five rats in which the dose response of the AVP antagonist was examined, the following results were obtained. The control rise in blood pressure after a $40 \mathrm{ng} / \mathrm{kg}$ bolus of AVP was from $117 \pm 2.6$ to $140 \pm 2.2 \mathrm{~mm} \mathrm{Hg}$, whereas after $0.5 \mu \mathrm{g} / \mathrm{kg}$ of AVP antagonist, the blood pressure response to the same dose of AVP $(40 \mathrm{ng} / \mathrm{kg})$ was not significantly different ( $117 \pm 2.5$ to $136 \pm 2.6 \mathrm{~mm} \mathrm{Hg}$ ). However, after $5 \mu \mathrm{g} / \mathrm{kg}$ of the AVP antagonist, the pressor response to $40 \mathrm{ng} / \mathrm{kg}$ of AVP was significantly less than the control response $(117 \pm 2.5$ to $140 \pm 2.2$ vs. $117 \pm 2.5$ to $126 \pm 2.7$ $\mathrm{mm} \mathrm{Hg}, P<0.001)$. The $10 \mu \mathrm{g} / \mathrm{kg}$ dose of the AVP

TABLE I

Dose Response of AVP Antagonist in Rats Receiving Exogenous AVP

\begin{tabular}{|c|c|c|c|c|}
\hline & \multirow{2}{*}{$\begin{array}{l}\text { AV'P } \\
\text { control }\end{array}$} & \multicolumn{3}{|c|}{ AVP plus AV'P antagonist } \\
\hline & & $0.5 \mu \mathrm{g} / \mathrm{kg}$ & $5 \mu \mathrm{g} / \mathrm{kg}$ & $10 \mu \mathrm{g} / \mathrm{kg}$ \\
\hline & & & $m m \mathrm{Hg}$ & \\
\hline$\Delta \mathrm{Blood}$ pressure & $23 \pm 2.2$ & $19 \pm 2.6$ & $9 \pm 2.7 *$ & $0 *+\downarrow$ \\
\hline
\end{tabular}

The dose of AVP was $40 \mathrm{ng} / \mathrm{kg}$ in all four groups.

$* P<0.001$ when compared with control.

$\ddagger P<0.001$ when compared with the studies using a $5 \mu \mathrm{g} / \mathrm{kg}$ dose of AVP antagonist.

antagonist totally abolished the pressor response to the same dose of AVP $(115 \pm 3$ to $115 \pm 3 \mathrm{~mm} \mathrm{Hg})$. This effect with $10 \mu \mathrm{g} / \mathrm{kg}$ of the AVP antagonist also was significantly different from the results with $5 \mu \mathrm{g} / \mathrm{kg}$ of the antagonist. The results of these studies are depicted in Table I.

Effect of AVP antagonist in water-diuresing rats and in rats after $24 \mathrm{~h}$ of fluid deprivation. The absence of an effect of the AVP antagonist in water-diuresing rats with suppressed endogenous levels of AVP is shown in Fig. 2. In this group of rats, mean arterial blood pressure was $128 \pm 4.2$ before and $129 \pm 4.6 \mathrm{~mm} \mathrm{Hg}$ after the AVP antagonist. The antagonist did, however, produce a significant antidiuretic response as urinary osmolality rose from $94 \pm 3.5$ to $702 \pm 22.1 \mathrm{mosmol} / \mathrm{kg} \mathrm{H}_{2} \mathrm{O}$ $(P<0.001)$.

The effect of the AVP antagonist in fluid-deprived rats is shown in Fig. 2. In these rats with high endogenous levels of AVP, the AVP antagonist caused a highly significant fall in mean arterial pressure, from $124 \pm 2.0$ to $110 \pm 2.9 \mathrm{~mm} \mathrm{Hg}(P<0.005)$. The urinary osmolality

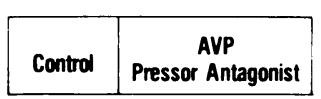

Water-diuresing

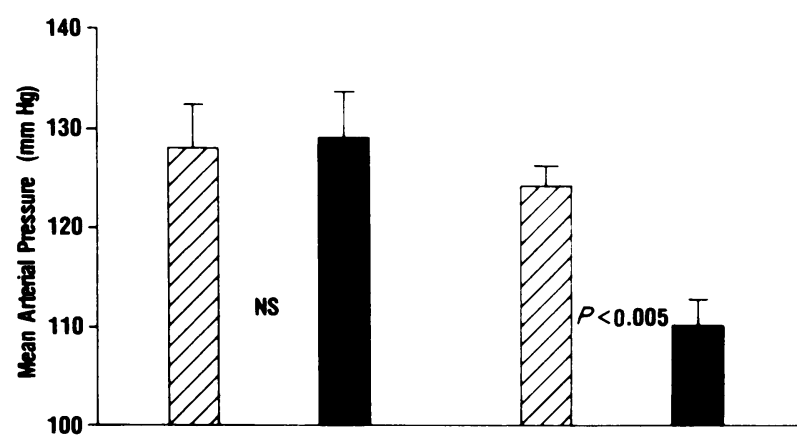

FIGURE 2 Effect of AVP pressor antagonist on blood pressure in water-diuresing (left two bars) and fluid-deprived (right two bars) rats. 

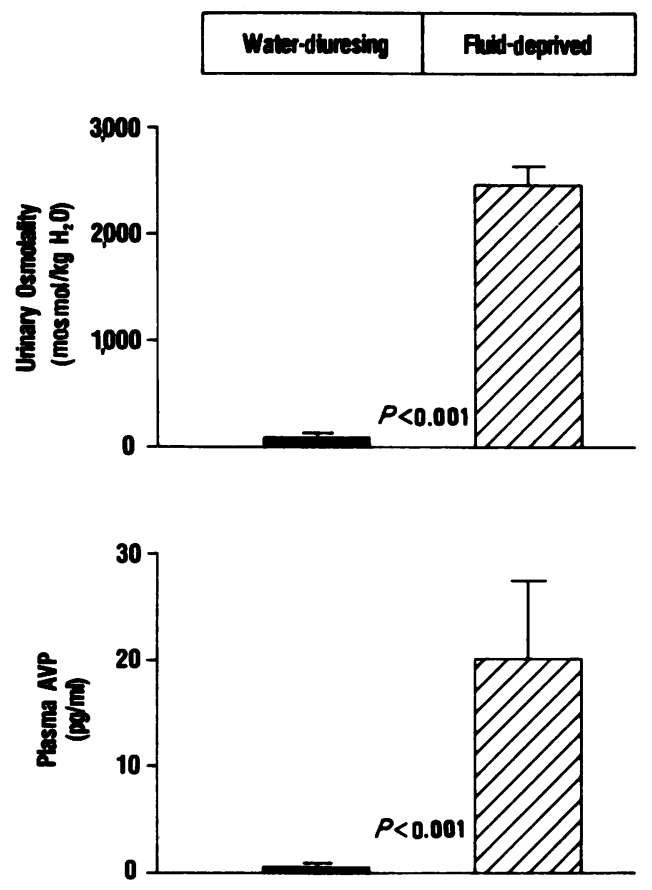

FIGURE 3 Urinary osmolality (above) and plasma AVP (below) in water-diuresing (solid bars) and fluid-deprived (hatched bars) rats.

and plasma vasopressin concentrations in the waterdiuresing and fluid-deprived rats are shown in Fig. 3. Highly significant differences in both urinary osmolality, $99 \pm 6.5$ vs. $2489 \pm 156 \mathrm{mosmol} / \mathrm{kg} \mathrm{H}_{2} \mathrm{O}(P$ $<0.001$ ), and plasma vasopressin concentrations, 0.5 \pm 0.006 vs. $21.6 \pm 7.1 \mathrm{pg} / \mathrm{ml}(P<0.005)$, were observed in these two groups of rats.

Effect of AVP antagonist in Brattleboro rats with and without exogenous AVP. Additional evidence for the specificity of the AVP antagonist was suggested by the following studies in Brattleboro rats with a congenital deficiency of antidiuretic hormone. Infusion of synthetic AVP resulted in a significant rise in blood pressure from $114 \pm 1.9$ to $128 \pm 2.0 \mathrm{~mm} \mathrm{Hg}(P<0.001)$. Discontinuation of the AVP infusion resulted in a prompt fall in blood pressure to $113 \pm 3.0 \mathrm{~mm} \mathrm{Hg}$ ( $P$
$<0.001)$. A second reproducible pressor response was observed after the infusion was begun again (113 \pm 3.0 to $127 \pm 2.5 \mathrm{~mm} \mathrm{Hg}, P<0.001$ ). Injection of [dPTyr (Me)]AVP during the second AVP infusion, however, resulted in a highly significant fall in blood pressure $(127 \pm 2.5$ to $115 \pm 2.2 \mathrm{~mm} \mathrm{Hg}, P<0.001)$. These results are summarized in Table II. In Brattleboro rats not receiving the AVP infusion, blood pressure was 112 $\pm 5.2 \mathrm{~mm} \mathrm{Hg}$ before and $112 \pm 5.4 \mathrm{~mm} \mathrm{Hg}$ after injection of the AVP antagonist. In another group of Brattleboro rats given an identical AVP pressor infusion, plasma AVP levels as determined by radioimmunoassay were $24.1 \pm 3 \mathrm{pg} / \mathrm{ml}$. These levels were not significantly different from levels measured in dehydrated Sprague-Dawley rats, thus supporting a pressor role of endogenous AVP during fluid deprivation dehydration.

Effect of AVP antagonist in nephrectomized rats after $24 h$ of fluid deprivation. The above results did not exclude the possible effects of the AVP antagonist to lower mean arterial pressure by inhibiting the reninangiotensin system. To examine this possibility, the AVP antagonist was administered to another group of fluid-deprived rats $24 \mathrm{~h}$ after bilateral nephrectomy. Abolition of the renin-angiotensin axis was confirmed by undetectably low PRA on the day of the study. In these nephrectomized rats the AVP antagonist caused a highly significant decrease in mean arterial pressure from $130 \pm 2.6$ to $118 \pm 3.1 \mathrm{~mm} \mathrm{Hg}(P<0.01)$. Mean arterial pressure was not significantly altered $(125 \pm 4.0$ vs. $130 \pm 3.6 \mathrm{~mm} \mathrm{Hg}$ ) when the blank solution was administered to another group of nephrectomized rats after $24 \mathrm{~h}$ of fluid deprivation.

Effect of AVP antagonist in rats receiving exogenous AII. In addition to the above experiments in nephrectomized rats, the AVP antagonist was given to a group of intact rats receiving a constant AII infusion (Fig. 4). In these rats, blood pressure rose from a control of 106 \pm 4.4 to $128 \pm 4.0 \mathrm{~mm} \mathrm{Hg}(P<0.001)$ and decreased to $102 \pm 4.2(P<0.001)$ after the infusion was discontinued. Mean blood pressure rose again after the infusion was restarted to $129 \pm 4.7 \mathrm{~mm} \mathrm{Hg}(P<0.001)$ and remained unchanged after injection of [DPTyr $(\mathrm{Me})]-$ AVP $(10 \mu \mathrm{g} / \mathrm{kg})$. Discontinuation of the AII infusion

TABLE II

Effect of Vasopressin Analogue to Block Pressor Response of AVP in Brattleboro Rats

\begin{tabular}{|c|c|c|c|c|c|}
\hline & Control & & AVP & Postcontrol & $\begin{array}{l}\text { AVP plus } \\
\text { analogue }\end{array}$ \\
\hline $\begin{array}{l}\text { Blood pressure, } \mathrm{mm} \mathrm{Hg} \\
P\end{array}$ & $114 \pm 22$ & $<0.001$ & $128 \pm 2$ & $113 \pm 3$ & \\
\hline $\begin{array}{l}\text { Blood pressure, } \mathrm{mm} \mathrm{Hg} \\
P\end{array}$ & $113 \pm 3$ & $<0.001$ & $127 \pm 3$ & $<0.001^{*}$ & $115 \pm 2$ \\
\hline
\end{tabular}

* Denotes significance between AVP alone and AVP plus analogue. 


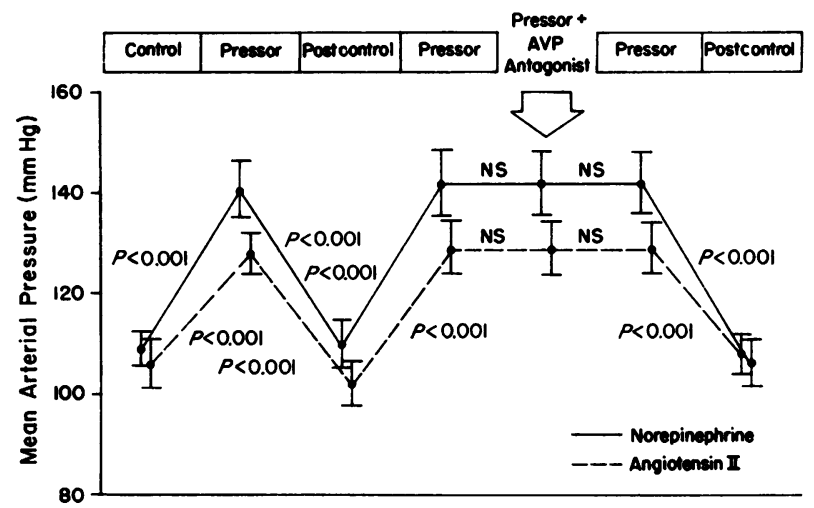

FIGURE 4 Effect of AVP pressor antagonist on blood pressure in rats receiving pressor doses of norepinephrine $(4 \mu \mathrm{g} / \mathrm{kg}$ per $\mathrm{min}$ ) and AII (0.3 $\mu \mathrm{g} / \mathrm{kg}$ per $\mathrm{min})$.

again resulted in a significant fall in blood pressure to $106 \pm 4.4 \mathrm{~mm} \mathrm{Hg}(P<0.001)$.

Effect of AVP antagonist in rats receiving exogenous norepinephrine. The mean control blood pressure in the five rats studied in this protocol was $109 \pm 3.4 \mathrm{~mm}$ $\mathrm{Hg}$ and during the norepinephrine infusion $(4 \mu \mathrm{g} / \mathrm{kg}$ per min) the blood pressure rose to $141 \pm 5.3 \mathrm{~mm} \mathrm{Hg}(P$ $<0.001$ ) (Fig. 4). After discontinuation of the infusion, blood pressure fell to $110 \pm 4.0 \mathrm{~mm} \mathrm{Hg}(P<0.001)$. When the norepinephrine infusion was restarted, blood pressure rose to $142 \pm 6.1 \mathrm{~mm} \mathrm{Hg}(P<0.001)$, and remained constant at $142 \pm 6.6 \mathrm{~mm} \mathrm{Hg}$ after administration of [dPTyr (Me)]AVP. Termination of the norepinephrine infusion lowered blood pressure to $108 \pm 4 \mathrm{~mm} \mathrm{Hg}$, a value not different from control.

Hemodynamic studies in 24-h fuid-deprived rats. The effects of the AVP antagonist on cardiac index, renal blood flow, total peripheral vascular resistance, renal vascular resistance, cerebral blood flow, and hepatic arterial blood flow in 24-h water-deprived rats are shown in Table III. Cardiac index remained unchanged at $383 \pm 13.9$ vs. $380 \pm 6.9 \mathrm{ml} / \mathrm{min}$ per $\mathrm{kg}$. The fall in blood pressure with the AVP antagonist was primarily due to a decrease in total peripheral vascular resistance, $0.35 \pm 0.015$ vs. $0.30 \pm 0.008 \mathrm{~mm} \mathrm{Hg} / \mathrm{ml}$ per min per $\mathrm{kg}(P<0.02)$. In spite of the fall in mean arterial pressure with the AVP antagonist, both renal blood flow $(5.7 \pm 0.31$ vs. $7.81 \pm 0.26 \mathrm{ml} / \mathrm{min}$ per $\mathrm{g}, P$ $<0.01)$ and hepatic arterial blood flow $(0.15 \pm 0.019$ vs. $0.22 \pm 0.014 \mathrm{ml} / \mathrm{min}$ per $\mathrm{g}, P<0.02$ ) increased. Cerebral blood flow remained unchanged at $0.95 \pm 0.11$ vs. 0.91 $\pm 0.07 \mathrm{ml} / \mathrm{min}$ per $\mathrm{g}$.

\section{DISCUSSION}

The present study was undertaken to investigate the potential vascular effects of AVP after $24 \mathrm{~h}$ of fluid deprivation in the rat. A newly synthesized analogue of AVP, [dPTyr (Me)]AVP, which possesses antagonist properties to the vasopressor action of AVP (7), was used in an effort to delineate any AVP-induced vascular effects of fluid deprivation. The studies were performed in conscious rats to avoid any consequences of anesthesia.

To test the efficacy of the AVP antagonist to block the vasopressor effects of exogenous AVP, normally hydrated rats were injected with two sequential boluses of a larger pressor dose $(40 \mathrm{ng} / \mathrm{kg})$ of synthetic AVP. Either a blank solution or the AVP antagonist was administered between the two sequential injections of AVP. In the studies using the blank solution, both sequential doses of AVP increased mean arterial pressure by $\sim 25 \mathrm{~mm} \mathrm{Hg}$. In contrast, when the rats were given the AVP antagonist prior to the second AVP dose, the pressor response was totally abolished. These studies therefore confirm that the AVP antagonist is extremely effective in blocking the vasopressor action of AVP. Studies also demonstrated a dose response of $0.5,5$, and $10 \mu \mathrm{g} / \mathrm{kg}$ of the antagonist to block the pressor response of $40 \mathrm{ng} / \mathrm{kg}$ of AVP.

The specificity of the AVP antagonist to block the pressor effect of AVP is further supported by several findings in the present study. Although the AVP antagonist totally blocked the pressor effect of AVP, the pressor effect of norepinephrine was unaltered by the antagonist. The possibility was also excluded of a depressor effect of the AVP antagonist which was mediated by blocking or suppressing angiotensin, since the AVP antagonist lowered blood pressure to a comparable degree in fluid-deprived rats with and without a renal source of renin. In addition, the AVP antagonist failed to alter the pressor response to exogenously

TABLE III

\begin{tabular}{lcccccc}
\hline & $\begin{array}{c}\text { Cardiac } \\
\text { index }\end{array}$ & $\begin{array}{c}\text { Renal blood } \\
\text { flows }\end{array}$ & $\begin{array}{c}\text { Total peripheral } \\
\text { vascular resistance }\end{array}$ & $\begin{array}{c}\text { Renal } \\
\text { vascular } \\
\text { resistance }\end{array}$ & $\begin{array}{c}\text { Cerebral } \\
\text { blood flow }\end{array}$ & $\begin{array}{c}\text { Hepatic arterial } \\
\text { blood flow }\end{array}$ \\
\hline & $m l / m i n / k g$ & $m l / m i n / g$ & $m m ~ H g / m l / m i n / k g$ & & $m l / m i n / g$ & $m l / m i n / g$ \\
Control & $383 \pm 13.9$ & $5.73 \pm 0.31$ & $0.35 \pm 0.02$ & $23.2 \pm 1.2$ & $0.95 \pm 0.11$ & $0.15 \pm 0.12$ \\
$P$ & $N S$ & $<0.01$ & $<0.02$ & $<0.001$ & NS & $<0.02$ \\
{$[$ dPTyr(Me)]AVP } & $380 \pm 6.9$ & $7.81 \pm 0.26$ & $0.30 \pm 0.01$ & $14.5 \pm 0.53$ & $0.91 \pm 0.1$ & $0.22 \pm 0.01$ \\
\hline
\end{tabular}


administered AII. The absence of a depressor effect of the AVP antagonist in water-diuresing rats with suppressed endogenous AVP would also support the specificity of the AVP antagonist to block the vascular effects of AVP. Although the effect of the AVP antagonist to lower blood pressure in the fluid-deprived rats did not seem to involve any antagonism of the vasoconstrictor effect of norepinephrine or angiotensin, it could have been related to a direct depressor effect of the AVP antagonist which was only manifest in a fluid-deprived state. The use of the AVP antagonist in Brattleboro rats suffering from diabetes insipidus argued against such an effect. These Brattleboro rats are chronically volume depleted, with a mean plasma osmolality of $332 \mathrm{mosmol} / \mathrm{kg} \mathrm{H}_{2} \mathrm{O}$ (12) as compared with a plasma osmolality of $302 \mathrm{mosmol} / \mathrm{kg} \quad \mathrm{H}_{2} \mathrm{O}$ in Sprague-Dawley rats after $24 \mathrm{~h}$ of fluid deprivation. Thus, if the depressor effect of the AVP antagonist in the volume-depleted state was due to an AVP-independent action, a depressor effect of the AVP antagonist should have occurred in the Brattleboro rats. The AVP antagonist did not, however, lower blood pressure in these volume-depleted Brattleboro rats. In addition, the AVP antagonist did reverse the pressor action of exogenous AVP infusions in Brattleboro rats, again supporting the specificity of the analogue.

The studies performed in rats undergoing a water diuresis also allowed further characterization of the antagonist as to whether the AVP antagonist also possesses agonist pressor properties. Many humoral antagonists possess some agonist properties, which may be most apparent when the endogenous hormone levels are suppressed. For example, the agonist effect of angiotensin antagonists on blood pressure is best observed in the sodium-replete state in which levels of the endogenous AII are diminished (13). Thus, although the AVP antagonist did not increase control blood pressure in the normally hydrated rat, an agonist effect might be apparent in water-diuresing rats with suppressed endogenous levels of plasma AVP. The AVP antagonist, however, did not alter control blood pressure in the water-diuresing rat, thus providing no evidence for agonist pressor properties of the agent. This conclusion was further supported by the observation that the AVP antagonist did not increase blood pressure in the Brattleboro rats suffering from central diabetes insipidus.

There was no evidence for any antidiuretic antagonist activity of the agent since urinary osmolality was unaltered in the fluid-deprived rats. The agent did, however, exert antidiuretic agonist activity, as it caused a prompt antidiuresis in the water-diuresing rats, with urinary osmolality rising from 94 to $702 \mathrm{mosmol} / \mathrm{kg} \mathrm{H}_{2} \mathrm{O}$. Thus, both AVP and synthetic AVP analogues may have potent antidiuretic properties. These findings, therefore, indicate that the AVP antagonist exerts a potent blocking effect on vascular AVP receptors in the absence of agonist activity, but activates collecting duct receptors governing epithelial water permeability, and thus causes an antidiuresis.

The absence of a detectable agonist effect on blood pressure of this AVP antagonist has potential implications for the future development of an antagonist to the antidiuretic activity of AVP. A proposed difficulty in developing an antidiuretic antagonist to AVP has been implied in the reserve receptor hypothesis (14). This hypothesis suggests that a maximal antidiuretic effect of AVP necessitates that only a very small percentage of collecting duct receptors need to be occupied by AVP. Thus, if an antagonist to the antidiuretic activity of AVP possesses any agonist properties, the antagonist effect could be obscured. Although the reserve receptor hypothesis may only apply to collecting duct and not vascular AVP receptors, it is important to note that the vasopressor antagonist used in the present study did not demonstrate any agonist pressor properties.

The most important studies performed in the present investigation were those undertaken in rats which were fluid-deprived for $24 \mathrm{~h}$. In these rats the mean endogenous plasma vasopressin level was $21.6 \mathrm{pg} / \mathrm{ml}$, as compared with $0.5 \mathrm{pg} / \mathrm{ml}$ in the water-diuresing rats. In contrast to the absence of an effect on blood pressure in the water-diuresing rat, the AVP antagonist lowered blood pressure by $\sim 15-20 \mathrm{~mm} \mathrm{Hg}$ in these fluid-deprived rats. These results provide strong evidence for an important vascular role of AVP in the conscious rat during fluid deprivation. Although exogenous AVP has been shown to depress cardiac output (15), it was demonstrated using the AVP antagonist in the present study that the primary effect of AVP was to increase total peripheral vascular resistance. In spite of a concomitant decrease in systemic blood pressure, the administration of the AVP antagonist was associated with an increase in renal and hepatic arterial blood flow. These results implicate a role of endogenous AVP to constrict renal and hepatic blood vessels during the fluid-deprived state. Although these results in the fluiddeprived rat indicate that the vascular effects of endogenous AVP primarily involve increasing vascular resistance, it is possible that after more severe hypovolemia, larger increases in plasma levels of AVP might also exert a negative inotropic effect on the heart.

In summary, [dPTyr (Me)]AVP was confirmed in vivo to be an extremely effective antagonist to the vasopressor properties of AVP. The AVP antagonist was not found to possess any agonist pressor effect in the waterdiuresing rat with suppressed endogenous AVP levels, but was found to possess antidiuretic properties. Use of the AVP antagonist in rats after $24 \mathrm{~h}$ of fluid deprivation (plasma AVP levels, $21.6 \mathrm{pg} / \mathrm{ml}$ ) demonstrated a significant fall in blood pressure and rise in renal and hepatic arterial blood flow. The effect on blood pres- 
sure occurred primarily due to a fall in peripheral vascular resistance. The AVP antagonist also lowered blood pressure in Brattleboro rats receiving exogenous AVP. A role of inhibition of the renin-angiotensin system or norepinephrine in the depressor effect of the AVP antagonist was excluded, as was a nonspecific effect in the volume-depleted Brattleboro rats. The present study, therefore, provides strong evidence that AVP is important not only as an antidiuretic hormone, but also in circulatory homeostasis during fluid deprivation in the conscious rat.

\section{ACKNOWLEDGMENTS}

Ms. Linda M. Benson and Ms. Shirley Artese for expert secretarial assistance.

This work was supported by a National Heart and Lung Institute Program Project grant HL-19928.

\section{REFERENCES}

1. Howell, W. H. 1898. The physiological effects of extracts of the hypophysis cerebri and infundibular body. J. Exp. Med. 3: 245-258.

2. Schrier, R. W., and T. Berl. 1975. Nonosmolar factors affecting renal water excretion. N. Engl.J. Med. 292: 81-88, $141-145$.

3. Schrier, R. W., T. Berl, and R. J. Anderson. 1979. Osmotic and nonosmotic control of vasopressin release. Am. J. Physiol. 236: F321-F332.

4. Schrier, R. W. 1974. "Inappropriate" versus "appropriate" antidiuretic hormone secretion (editorial). West. J. Med. 121: $62-64$.

5. Schrier, R. W., and T. Berl. 1972. Mechanism of the antidiuretic effect associated with interruption of parasympathetic pathways. J. Clin. Invest. 51: 2613-2620.
6. Dunn, F. L., T. J. Brennan, A. E. Nelson, and G. L. Robertson. 1973. The role of blood osmolality and volume in regulating vasopressin secretion in the rat.J. Clin. Invest. 52: 3212-3219.

7. Bartrum, R. J., D. Berkowitz, and N. K. Hollenberg. 1974. A simple radioactive microsphere method for measuring regional flow and cardiac output. Invest. Radiol. 9: $126-132$.

8. Bankowski, K., J. Halder, M. Manning, and W. H. Sawyer. 1978. Design of potent antagonists of the vasopressor response to arginine vasopressin. J. Med. Chem. 21: $850-853$.

9. Robertson, G. L., E. A. Mahr, S. Athar, and T. Sinha. 1973. Development and clinical application of a new method for the radioimmunoassay of arginine vasopressin in human plasma. J. Clin. Invest. 52: 2340-2352.

10. Anderson, R. J., R. Pluss, A. Berns, T. Jackson, P. Arnold, R. W. Schrier, and K. M. McDonald. 1978. Mechanism of effect of hypoxia on renal water excretion. J. Clin. Invest. 62: 769-777.

11. Stockigt, J., R. Collins, and E. Biglieri. 1971. Determination of plasma renin concentration by angiotensin I immunoassay. Circ. Res. 28,29(Suppl. 1): 175-191.

12. Gellai, M., B. R. Edwards, and H. Valtin. 1979. Urinary concentrating ability during dehydration in the absence of vasopressin. Am. J. Physiol. 237: F100-4.

13. Strewler, G. J., K. J. Henricks, C. R. Guiod, and N. K. Hollenberg. 1972. Sodium intake and vascular smooth muscle responsiveness to norepinephrine and angiotensin in the rabbit. Circ. Res. 31: 758-766.

14. Ariens, E. J., J. J. Rossum, and P. C. Koopman. 1960. Receptor reserve and threshold phenomena. I. Theory and experiments with autonomic drugs tested on isolated organs. Arch. Int. Pharmacodyn. Ther. 127: 454-478.

15. Nakano. J. 1974. Cardiovascular responses to neurohypophyseal hormones. In Handbook of Physiology. E. Knobil and W. H. Sawyer, editors. American Physiological Society, Washington, D. C. Sec. 7. 395-442. 